\title{
DEVELOPMENT OF MEMS CONSTRUCTION CONNECT DEVICES WITH A SELF-TEST CONNECTIONS
}

\author{
Igor Sh. Nevliudov, Olexandr I. Filipenko, Victor A. Palagin, \\ Ievgenii A. Razumov-Fryziuk, Victoria V. Nevliudova, Darya V. Gurina \\ Kharkiv National University of Radio Electronics, Kharkiv, Ukraine
}

Background. A large part of modern electronic components used in the ET, having a high electro-physical characteristics stated, quite often don't match passport data, have hidden defects that are due to the complexity and high level of integration (processor, the FPGA etc) is difficult to identify timely. This imposes on producers of ET additional requirements on the organization of the input and functional control of finished products and controlling with a high level automation and complexity devices.

Objective. The aim of the paper is the development of the original design-technological solution of multiprobe contact device for control chips in BGA packages that is distinguished with simultaneously control a large number of outputs with a high density of their location, low cost, low weight and size parameters and the ability to connect quality control.

Methods. High-quality, uniform contacting of the multiprobe contact device for controlled chip is carried out by a pneumatic clamping of probes lying on the flexible cable.

Results. A multiprobe contact device and the topology of the holding cable was designed, simulation of the stress-strain state was made, which occurs when pressing the probes of flexible clamping cable to circuit connections, experimental studies of transient resistance flexible cable - output circuits were carried out.

Conclusions. The simulation and experimental researches suggest that the proposed structural-technological solution allows you to control chips in BGA packages with number of pads to several hundred and location step up to $500 \mu \mathrm{m}$.

Key words: BGA; multiprobe contact device

\section{Electric control chips in BGA packages.}

A large part of modern electronic components used in the ET, having a high electro-physical characteristics stated, quite often don't match passport data, have hidden defects that are due to the complexity and high level of integration (processor, the FPGA etc) is difficult to identify timely. This imposes on producers of ET additional requirements on the organization of the input and functional control of finished products and controlling with a high level automation and complexity devices $[1,2]$.

In the area of control of electrical components parameters outlined several trends. The first of them the implementation principle of peripheral, boundary testing in the design of the components (boundary testing according to IEEE-1149 standard). To verify the health in this embodiment provides conclusion of key points on the external peripheral set of contacts, which connect more simple than to internal (in the BGA / CSP and others.).

Another principle is used in the FPGA. The manufacturer is developing a scheme of programming devices and tests for testing products that require additional input devices for testing data [3].
The third principle - to use for testing programmable connect high-speed devices with "flying probe" (up to 60 connections per minute).

Also electric control of multilayer back plane is performed by automated controlling complexes (IRCGS-2400, Temp-F, ASK-MKI, ART-9411, etc.) that use switchboard as is "bed-of-nails"- the matrix of spring-loaded contacts or matrix of needle probes, creating pressure on the contact areas controlled circuit boards due to the loss of stability (USC universal contact system USK-1) (Fig. 2).

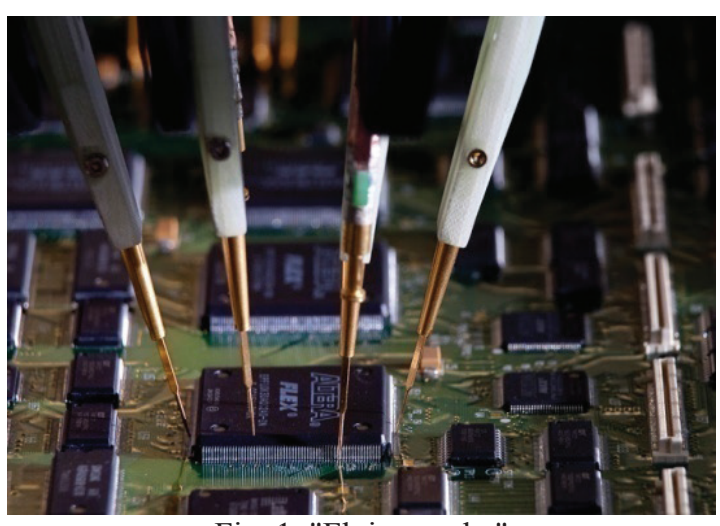

Fig. 1. "Flying probe" 


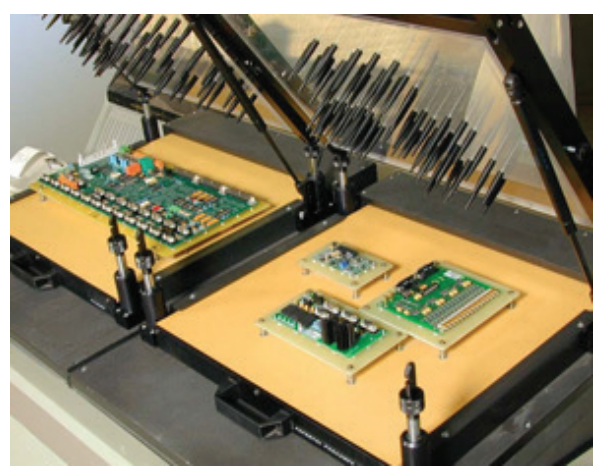

Fig. 2 - "Bed-of-nails"

The main controllable parameters in multilayer back plane are the integrity of the conductors and the absence of short-circuits between separated circuits [4].

As the number of connections securely connects devices falls. There are control systems with number of connection points 4000, 8000, 10000 and even 16000 . The complexity of manufacture, repair, maintenance and the cost of these devices are increasing.

In most cases, control devices of chips in BGA packages are expensive and intended for large-scale and mass-production and currently is necessary to develop cheaper devices for BGA chips [5].

This fact is used in the development of a number of constructive and technological solutions for the multiprobe contact device (MCB) control of electrical parameters of multilayer back plane (MBP) (PCB, thin and thick film) and for the input and functional control of electronic components (EC) with matrix pin [Ukraine Patents № 82405, 2008; № 95190, 2011; №97538, 2012; 98539, 2012].

\section{Description of the MCB design}

Proposed multiprobe contact devices for control of electronic components (EC) [Ukraine Patents № 95190] having the ability to test (self-test and self-monitoring) contacting each single probe with a corresponding output of the controlled EC that provides intelligence properties for connect devices due to the possibility of obtaining information about the existence of contact with any output of EC and increasing the reliability of the testing EC, performed in the following way [6-9].

MCB (Fig.3) comprises corps-base 1, contacts-probe as pads on the pressing plate flexible multilayer plane 2 , with conductor, made of foil dielectrics which are pressed to the controlled electronic component 4 by the compressed air, cover 5 , the sealing gasket 7 , which provides tightness of case, the fixing member 6 , lattice 3 (provides protection from sagging) and air outlet.

According to the invention, each individual probearea (Fig. 4) divided into two not connected electrical parts that are designed for contacting with ball output of $\mathrm{EC}$ as that separate parts probe became electrically connected between themselves only by contacting at least two parts for one output and these separate parts are connected particular conductors of the board at its opposite end to the contacting zone with standard flat connector.

The main technical parameters of MCB:

- probe arrangement density - up to $250 \mu \mathrm{m}$;

- transition resistance - units $\mu \mathrm{Ohm}$;

- the number of elements controlled in the same time - to several thousand depending on the density of their location;

- connection to automated measuring complexes by ZIF-connectors.

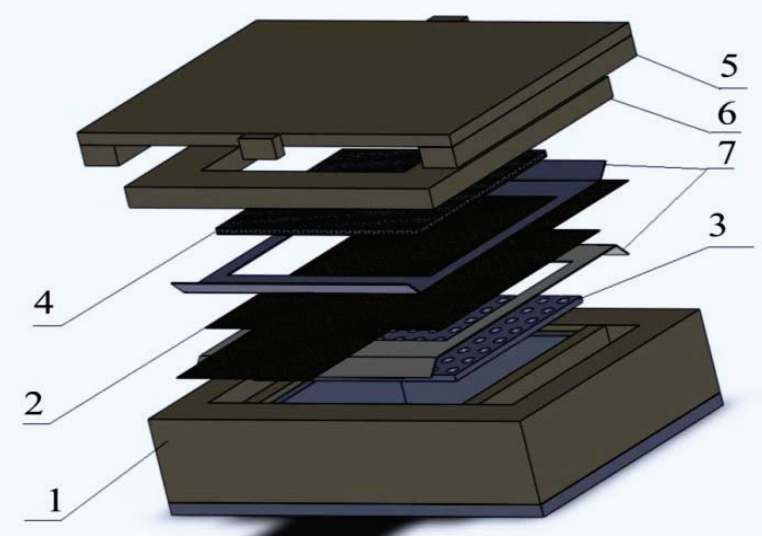

Fig. 3. 3D model of MCB

Wiring plan BGA components to MCB is presented in Fig. 4.

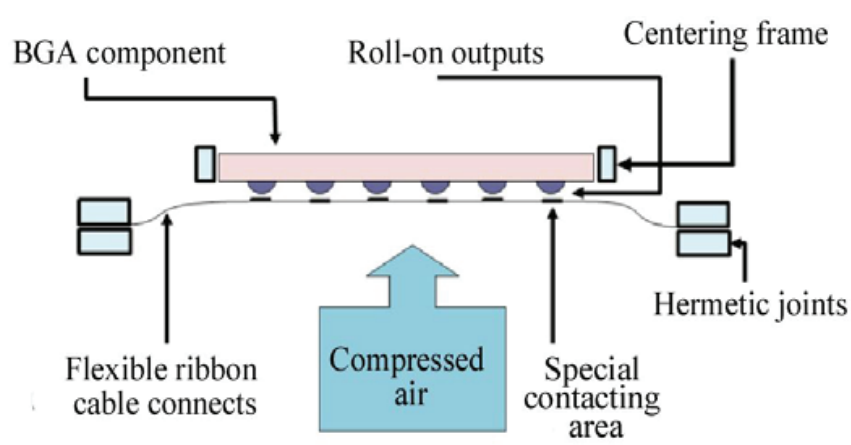

Fig. 4. Wiring plan BGA components to $\mathrm{MCB}$

\section{Simulation of stress-strain state of the pressing cable}

Pre-simulated stress-strain state occurs when the probes of flexible clamping cable is pressed to the outputs of the chip in BGA package using the finite element method. 
Simulation results are shown in Fig. 5-8. When modeling was considered as a uniform matrix arrangement of the chip outputs as the absence part of the outputs of the matrix. Simulation results confirmed the possibility of practical application of the proposed design.

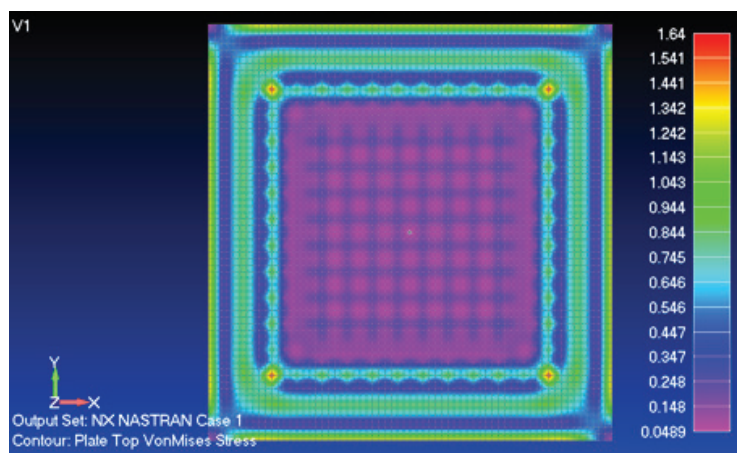

Fig. 5. Modeling of stress in the plate when pressed regular structure

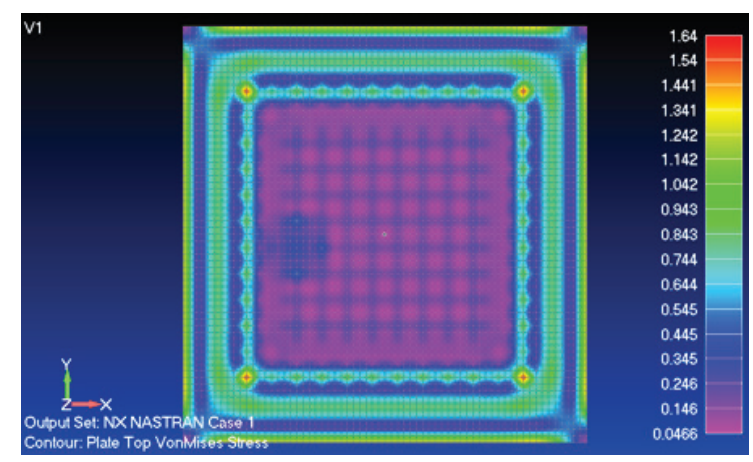

Fig. 6. Modeling of stress in the plate when pressed not regular structure

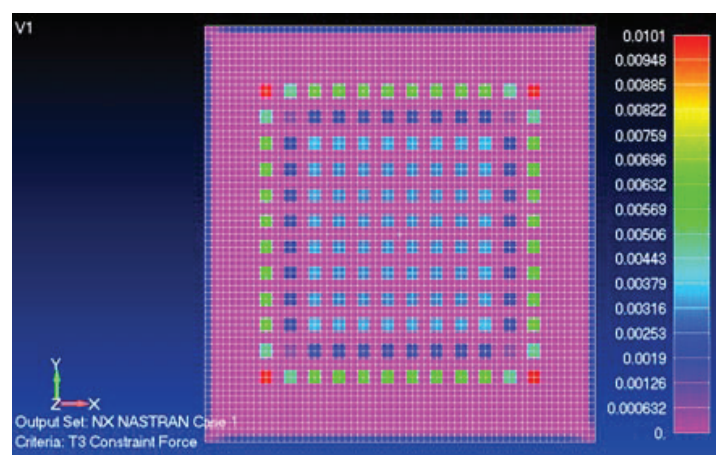

Fig. 7. Modeling of the reaction force when balls are pressing of regular structure

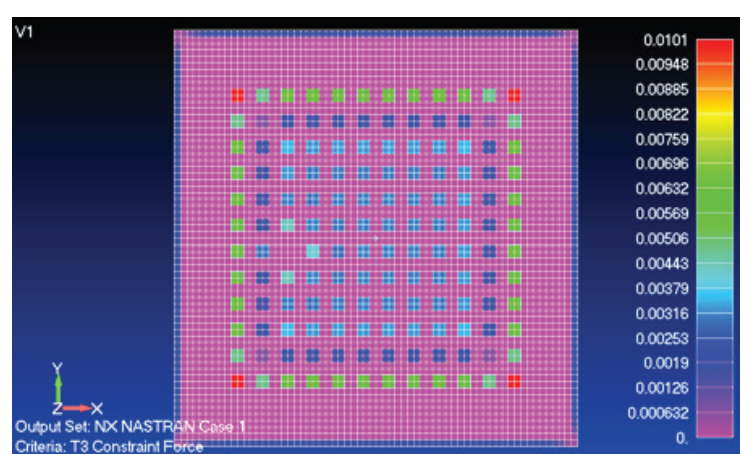

Fig. 8. Modeling of the reaction force when balls are pressing of not regular structure

\section{Development of the construction of the holding cable}

As a control object to create a prototype $\mathrm{MCB}$ were selected chips in the FG-320 corps (Fig.9).

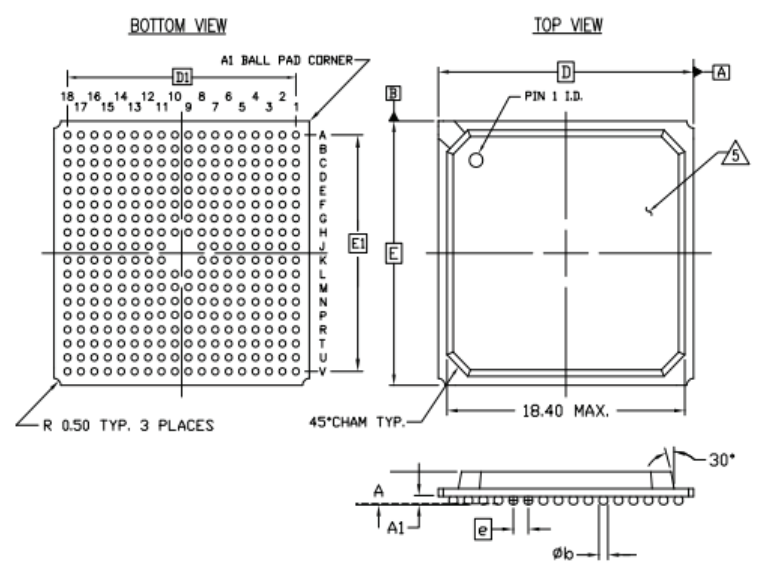

Fig.9. MCB corps of the FG-320 chip

The reason for choosing this type of corps is the high complexity of the design topology pressing plate multiprobe connect devices due to a large number of control elements (pins) - 320 pieces, as well as the high density of their location - lead spacing $1 \mathrm{~mm}$.

The most technologically complicated and expensive element of the prototype of multiprobe connect devices is a pressing plate. Was decided to choose as a material the brand polyimide PDI-35 foiled by aluminum, which is characterized by good technological, temporal and climatic characteristics.

The layout topology of the pressing plate is made in two layers, and is shown in Fig. 10 and 11. 


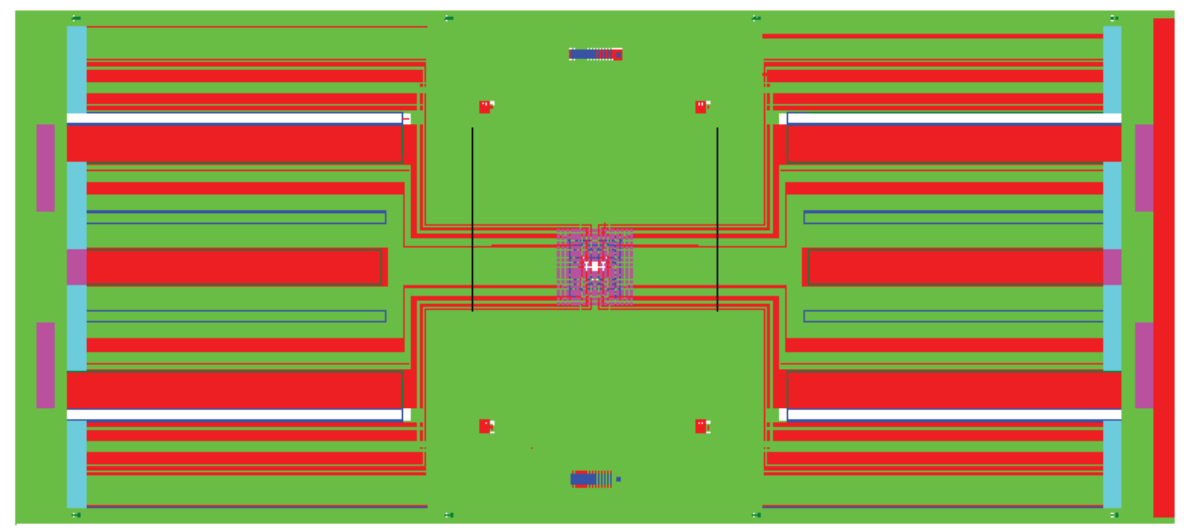

Fig. 10. Topology of the pressing plate (operational and technological areas)

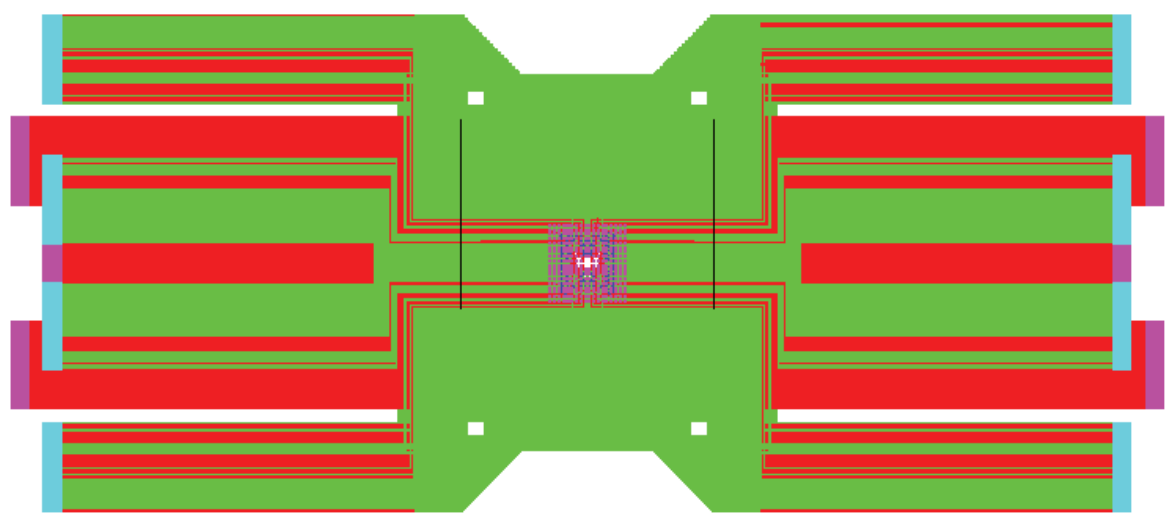

Fig. 11. Topology of the pressing plate (operational areas)

The first layer of the pressing plate contains contact elements (probes) and partially implemented conductors wiring, it also has ten external cables through which MCB connected to an external measuring apparatus, five with two opposite sides. The width of the conductor pressing plate is $75 \mu \mathrm{m}$, the minimum distance between conductors $75 \mu \mathrm{m}$.

In the second layer is performed wiring of the remaining conductors also there are eight external loops through which MCB connected to an external measuring apparatus, four on two opposite sides.

Interlayer compounds performed by ultrasonic welding through the windows in the polyamide $150 \mathrm{x}$ $150 \mu \mathrm{m}$, Fig. 12.

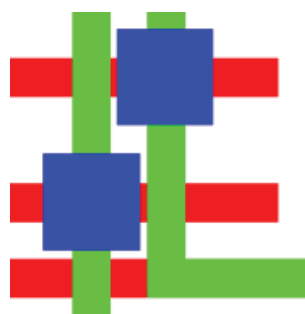

Fig. 12. The windows in the polyamide for interlayer compounds ultrasonic welding
Each probe of the pressing plate is divided into two separate contact elements. This type of probe is used because the complexity of contacting devices for monitoring electrical parameters of MBP increases with the number of control points, reducing the size of contact pads. It reduces the reliability of control, in resulting to avoid control errors are entered manually recheck the operation of individual circuit boards.

The main controlled parameters of the boards are integrity of the conductors and the absence of short circuits between separated circuits. In automatic control of these parameters, and using the connection to the contact pads of circuit boards with a single probe errors can occur in two forms:

- under the control of the integrity of the conductors of the non-contact probe to one end of the conductor it will be rejected as having a discontinuity, i.e. possible the rejected of suitable products;

- under the control of the insulation separated circuits in the absence of contact with one of the probes with a controlled circuit short-circuit will not be detected even when it is available, i.e. can pass the defective product. 
MCB probe is performed in the form of two independent contact elements. From every of the contact element launched one conductor on the outer end of cable. This separation of the probe ensures that the contact between separated parts with small displacements of the contact pads and probe of the connect devices on the axes in the plane of the board.

Thus, connect devices provides the ability to control the availability of contact each of the plurality of probes with a corresponding controlled chip output. In addition to increasing the reliability of contact, obtained the ability to control the availability of the contact. The ability to control the contact as described above eliminates the control error of the first and second kind.

The dimensions of the pressing plate probe is 400x400 $\mu \mathrm{m}$. Probes of the pressing plates and elements connecting external cable is necessary to cover a layer of nickel, which will not allow the oxide of aluminum foil and increase the contact resistance.

In order to reduce the cost of manufacturing the prototype layout multiprobe connect devices has been simplified - reduced number of external (pin) cable one in the first layer, and two in the second. In the figure is shown the topology of the process and working zones pressing plate (Fig. 13).

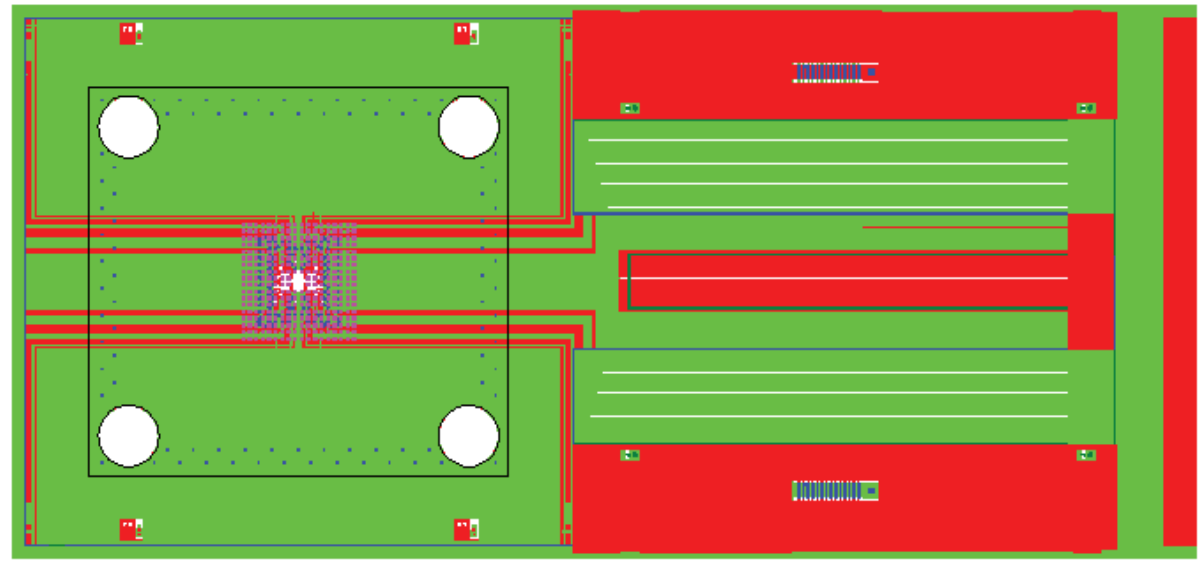

Fig. 13. - The topology of the process and working zones pressing plate

Prototyping performed in conjunction with a number of enterprises of Kharkov.

In the manufacture of the first prototype was found a number of technological deficiencies: alignment inaccuracies (Fig. 14-15), conductor break (Fig. 16-17) and short-circuiting (Fig. 18).

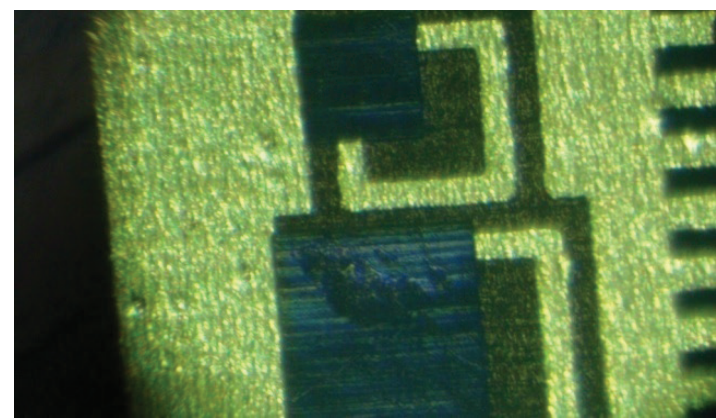

Fig. 14. Poor-quality combination of masks for etching of aluminum and nickel deposition (alignment member)

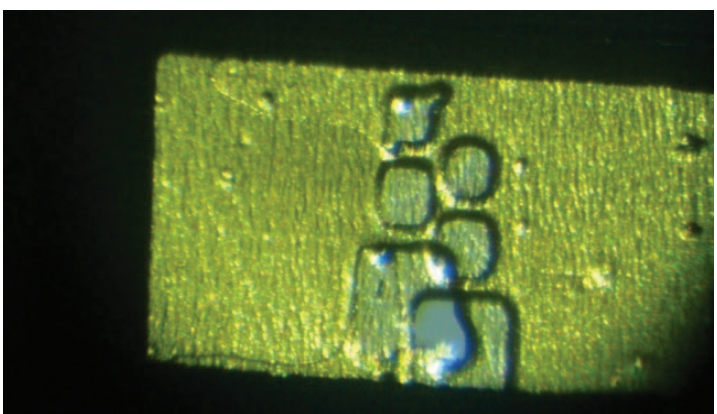

Fig. 15. Poor-quality alignment layers of the pressing plate

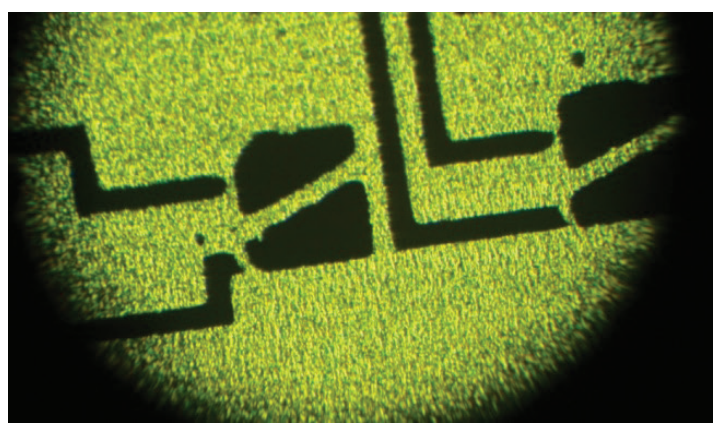

Fig. 16. Conductor break near MBP probe 


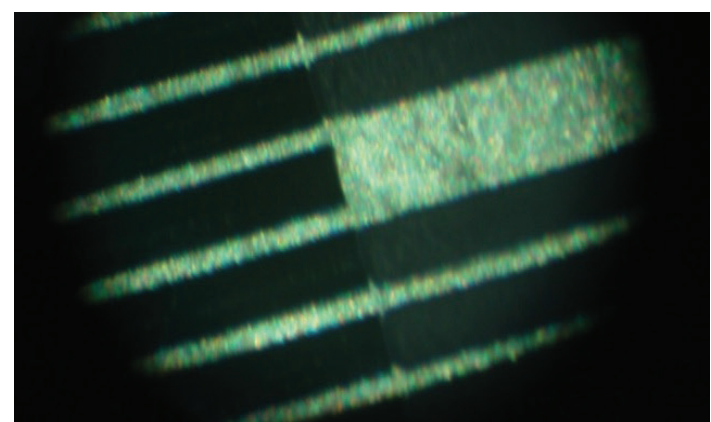

Fig. 17. Conductor break near external output of the pressing plate

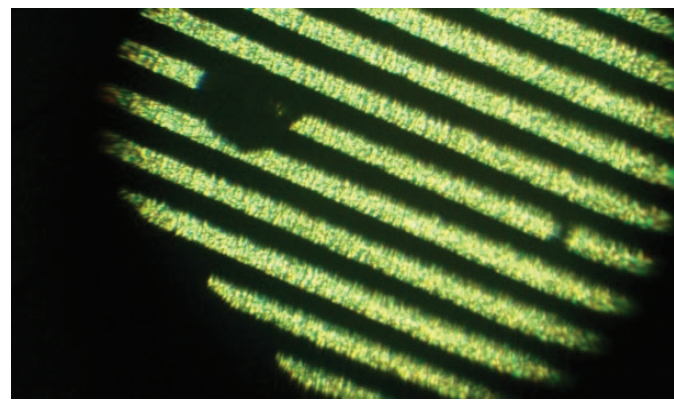

Fig. 18. Short-circuiting

In the manufacture of the second prototype these shortcomings have been addressed and resolved. View of the second prototype of the MBP made in conjunction with Research Technological Institute of Instrument Engineering shown in Fig. 19 and 20.

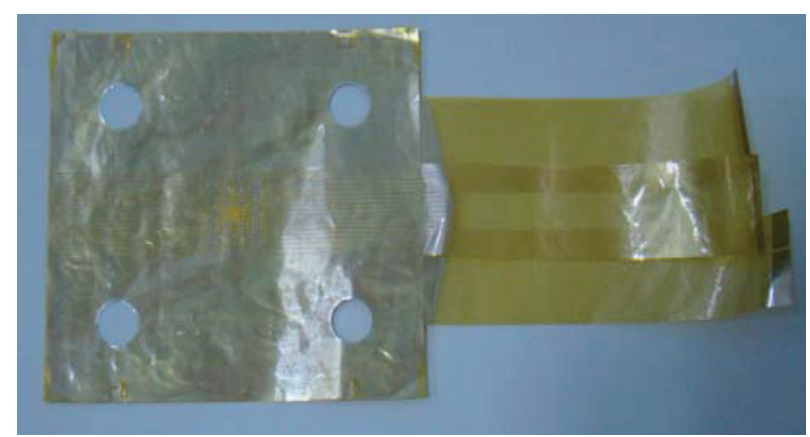

Fig. 19. The prototype of the pressing plate (the contact side)

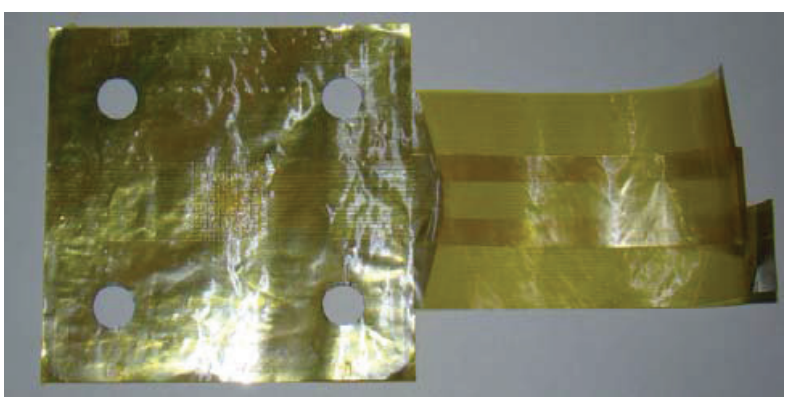

Fig. 20. The prototype of the pressing plate (back side)
Figures $21-25$ is an enlarged view of elements of the pressing plate prototype.

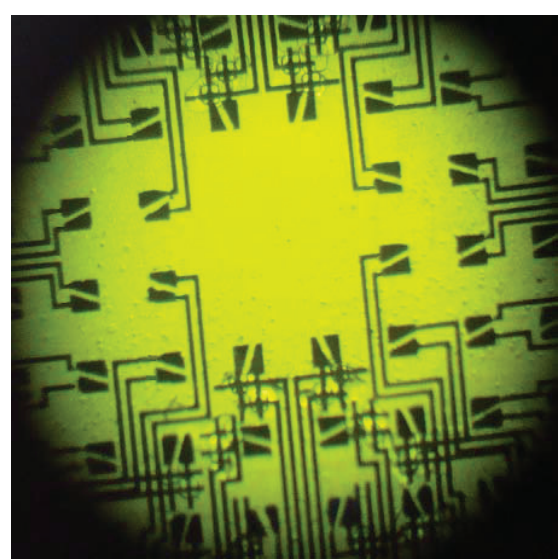

Fig. 21. The pressure plate (general view)

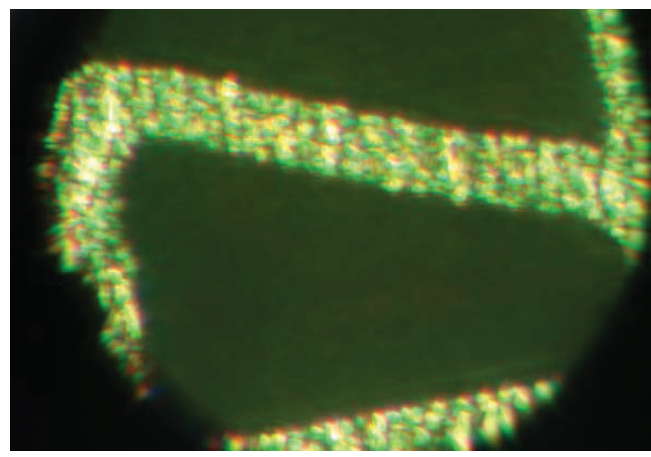

Fig. 22. Probe

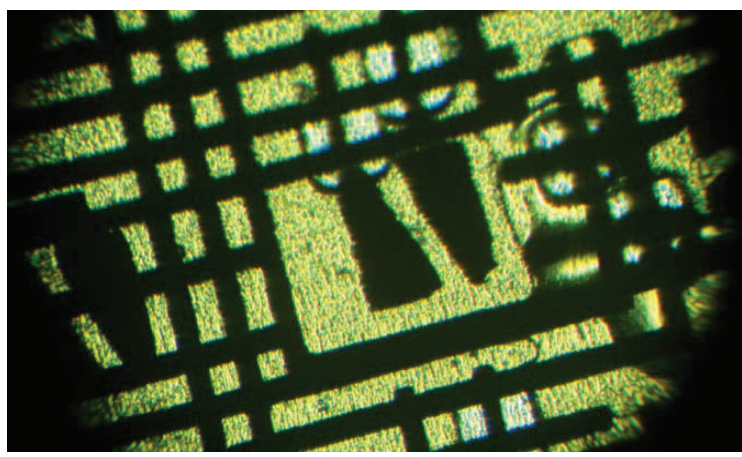

Fig. 23. Welded joint, welding window, probe.

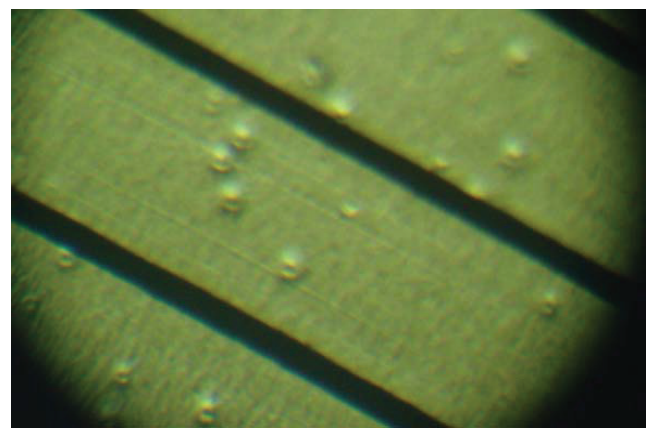

Fig. 24. Conductors 


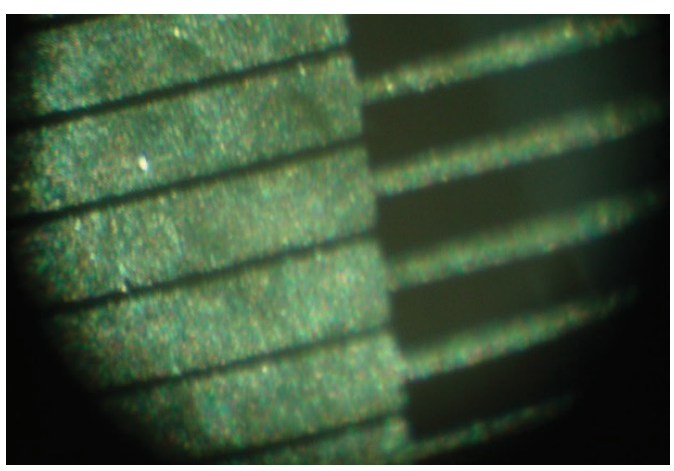

Fig. 25. Elements of connecting external cable

\section{Analysis of resistances}

One of the major problems in testing the BGAcomponents is to obtain a stable contact resistance. Determining the distribution of contact resistance plays an important role in assessing the operational reliability of the contacting device (connector).

The deterioration or violation of the connector contacts can significantly reduce the result of the first test and increase the retest.

At the control of electronic components is very important to accurately measure the electrical parameters, as the lack of precision of control can lead to defect of an entire batch of products or recognition of unfit - defective products.

This is especially important during the functional control of the EC, which requires the measurement of functional dependencies.

In the manufacturing process by measuring electrical parameters on equipment may be affected by such negative factors as depreciation of equipment, contamination of equipment or product, the human factor.
Therefore, the aim of this research is to analyze the MCB parameters that can affect the reliability and accuracy of the control of EC. The main investigated parameters selected transition resistance in the contact area "roll-on output-probe of MCB".

Transient resistance - a sharp increase in resistance at the transition of current from one part to another.

Conducted an experiment to determine the allowable contact force for pressing the polyimide cable to the control component with the matrix roll-on outputs by measuring the transition resistance contacts BGAcomponent polyimide connected cable. BGAcomponent models used to measure transition resistance («dummies»), cover was opened, it giving access to contacts on both sides of the EC.

The measurements were performed for different numbers of outputs which connected to the MCB. For contacts constantly were soldered conductors.

To measure these values was used method of for probe which eliminates the influence of the resistance connecting cables of the voltmeter because of its high input resistance, and the resistance connecting cables the power source - by adjusting the amount of current required.

The essence of the experiment is to analyze the variation of resistance depending on pressure changes in the "roll-on polyimide output film" contact group. To ensure the necessary pressure values used weights from 1 to $150 \mathrm{~g}$.

Table 1 and Table 2 shows the average results obtained during the experimental values based on calculation of the pressure in each roll-on individually.

Depending obtained in the experiment shown in Fig. 26 and Fig. 27.

Table 1. The results of measuring the transition resistance

\begin{tabular}{|c|c|c|c|c|c|c|}
\hline \multirow{2}{*}{ Power, $N$} & \multicolumn{7}{|c|}{ Resistance, $m$ Ohm } \\
\cline { 2 - 7 } & 1 & 2 & 3 & 4 & 5 & 6 \\
\hline 0,01 & 0,12 & 0,114 & 0,114 & 0,114 & 0,114 & 0,114 \\
\hline 0,02 & 0,12 & 0,114 & 0,114 & 0,114 & 0,114 & 0,114 \\
\hline 0,05 & 0,117 & 0,113 & 0,114 & 0,114 & 0,114 & 0,114 \\
\hline 0,1 & 0,116 & 0,11 & 0,114 & 0,114 & 0,114 & 0,114 \\
\hline 0,2 & 0,118 & 0,109 & 0,108 & 0,113 & 0,108 & 0,114 \\
\hline 0,5 & 0,108 & 0,108 & 0,108 & 0,107 & 0,107 & 0,107 \\
\hline 1,0 & 0,108 & 0,107 & 0,107 & 0,107 & 0,107 & 0,107 \\
\hline 1,5 & 0,107 & 0,107 & 0,107 & 0,107 & 0,107 & 0,106 \\
\hline
\end{tabular}


Table 2 - Average results obtained values

\begin{tabular}{|c|c|}
\hline Power, $N$ & Resistance, $m$ Ohm \\
\hline 0,000575 & 0,115 \\
\hline 0,001151 & 0,115 \\
\hline 0,002876 & 0,114333333 \\
\hline 0,005753 & 0,113666667 \\
\hline 0,011505 & 0,111666667 \\
\hline 0,028763 & 0,1075 \\
\hline 0,057526 & 0,107166667 \\
\hline 0,086289 & 0,106833333 \\
\hline
\end{tabular}

From these dependences that when the pressing a range from 0,03 to $0,09 \mathrm{~N}$ - also continues to force of from 0,01 to $0,03 \mathrm{~N}$ resistance sharply drops in decrease, but fairly slowly.

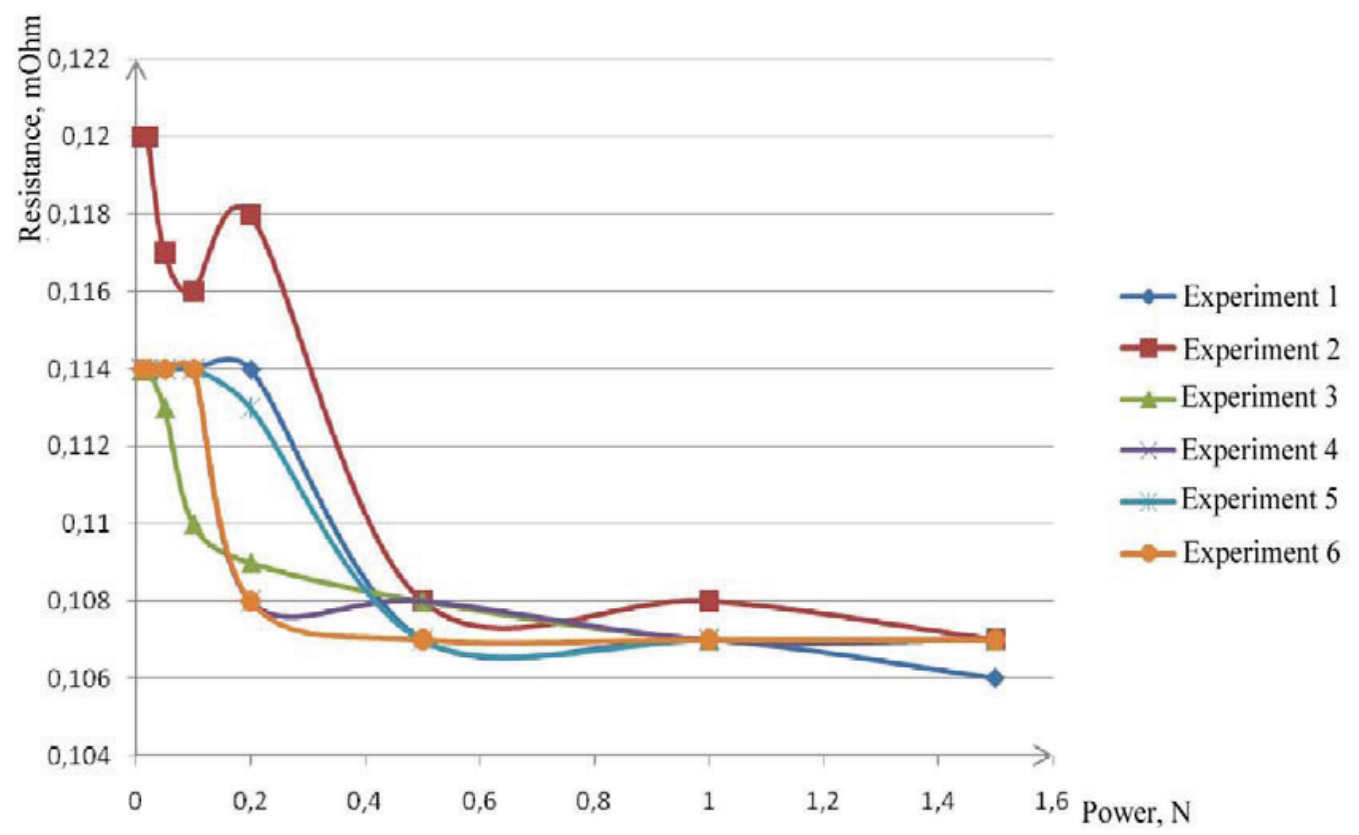

Fig. 26. Dependence of resistant from pressing force of contacts for 6 experiments

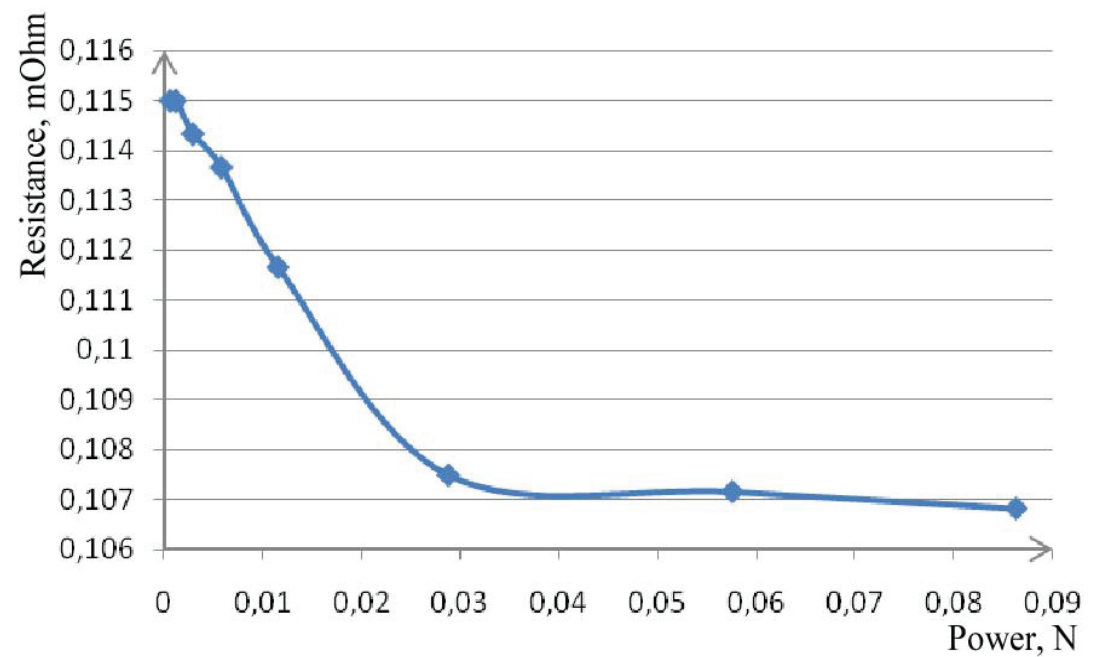

Fig. 27. Average values of the resistance based on the pressure calculation for each separately roll-on 
After analyzing the results, we can conclude that in the MCB case when connected cable is squeezing by the compressed air to the BGA-component value of the force acting on the one roll-on output should be in the range $0,07-0,3 \mathrm{~N}$.

The results are also consistent with the requirements of the standards to the value of the contact force under the control of EC using multiprobe connected devices.

The minimum allowable pressure of compressed air in the MCB case based on the requirements ensuring necessary transitional resistance in the contact area of the probe with roll-on output of EC at the control of circuit in the FG-320 case should be $0.056 \mathrm{MPa}$.

\section{Conclusions}

The article suggests a fundamentally new design and the results of the manufacture and testing of prototype multiprobe contact device to control circuits in the BGA package, which has a number of advantages:

- low cost in comparison with analogues;

- small overall dimensions;

- the ability to simultaneously control a large number of chip output with a high density of their placement (as provided in article topology step controlled conclusions $1 \mathrm{~mm}$, number 320 );

- uniformity of pressing probes to controlled conclusions (confirmed in the article presented the results of the simulation);

- the existence of intellectual property, which are as self-test the quality of the connection due to a constructive solution - separation MCB probe into several pieces.

\section{References}

1. Control System Design for Height Measurement of BGA Balls Based on Timed Automata / Hengsheng Wang, Zimin Lu, Fuliang Wang // IEEE Transactions on Components, Packaging and Manufacturing Technology (Volume: 4, Issue: 3, March 2014).

2. IPC 7095B. Design and Assembly Process Implementation for BGAs.

3. Electronics interconnect process / V.V. Semenets, John Kratz, I.SH. Nevlyudov, V.A. Palagin Kharkiv: LLC "KOMPANIYA SMIT” 2005-p.432.
4. Flip Chip Ball Grid Array Package Reference Guide Texas Instruments Incorporated, Literature Number: SPRU811A. May 2005.

5. Ching Mai Co., Ming-Kun Chen, Yu-Tszung Huang, Shen-Li Fu Testing reliability of the BGA components // Technologies in the electronic industry. 2009. - №4. Pp. 38-42.

6. F. Wang, J. Qin, L. Han, H. Wang, "Height measurement of micro-solder balls on metal pad by white light projection", IEEE Trans. Compon. Packag. Manuf. Technol., vol. 2, no. 9, pp. 1545-1549, Sep. 2012.

7. A. Teramoto, M. Yamada, T. Murakoshi, M. Tsuzaka, H. Fujita, "High speed oblique CT system for solder bump inspection", Proc. IEEE 33rd Annu. Conf. IECON, pp. 2689-2693, 2007-Nov.

8. Y. Hsu-Nan, T. Du-Ming, Y. Jun-Yi, "Full-field 3-D measurement of solder pastes using LCD-based phase shifting techniques", IEEE Trans. Electron. Packag. Manuf., vol. 29, no. 1, pp. 50-57, Jan. 2006.

9. R. Schnelder, A. Schick, P. Kollensperger, T. Ninomlya, "High-speed optical three-dimensional scanner for automatic solder joint inspection", Opt. Eng., vol. 36, no. 10, pp. 2878-2885, Oct. 1997

10. Nevlyudov I.SH., Palagin V.A., RazumovFryzyuk E.A., Zharikova I.V., Kostenko Z.I. MEMSinterface of multipoint automatic controlling systems. Patent for invention number 98539 Ukraine МПК H05K 3/40, publ. 25.05.2012, Bull. №10, 2012.

11. Nevlyudov I.SH., Palagin V.A., Borshchev V.N., Razumov-Fryzyuk E.A., Zharikova I.V. MEMS multiprobe contact device. Patent for invention number 97538, Ukraine МПК Н05K 1/11, publ. 27.02.12, Bul. №4, 2012.

12. Nevlyudov I.SH., Palagin V.A., Borshchev V.N., Razumov-Fryzyuk E.A., Zharikova I.V. MEMS multiprobe connecting device. Patent for invention number 95190, Ukraine МПК H05K 3/40, publ. 11.07.2011, Bul. №13, 2011.

13.Semenets V.V., Nevlyudov I.SH., Palagin V.A., Razumov-Fryzyuk E.A. Multiprobe contact device. Patent for invention number 82405. МПК H05K 1/00, publ. 26.11.2007, Bul. №19.

Received in final form on September 16, 2016

\section{Невлюдов І.Ш., Филипенко О.І., Палагін В.А., Разумов-Фризюк С.А., Невлюдова В.В., Гуріна Д.В.

Проблематика. Значна частина сучасних електронних компонентів, що застосовуються в електронній техніці, володіючи високими заявленими електрофізичними характеристиками, досить часто не відповідають паспортним 
даним, мають приховані дефекти, які через складність та високий рівень інтеграції (процесори, FPGA і ін.) складно своєчасно виявити. Це накладає на виробників ЕТ додаткові вимоги щодо організації вхідного і функціонального контролю виробів і використання контролюючих пристроїв високого рівня автоматизації і відповідно складності.

Мета досліджень. Розробка оригінального конструктивно-технологічного рішення багатозондового контактного пристрою для контролю мікросхем в корпусах BGA, яке відрізняється можливістю одночасного контролю великої кількості виводів 3 високою щільністю їх розташування, низькою собівартістю, малими масогабаритними параметрами і можливістю контролю якості підключення.

Методика реалізації. Якісне, однорідне контактування багатозондового контактного пристрою до контрольованої мікросхемі здійснюється за рахунок пневматичного притиснення зондів, розташованих на гнучкому шлейфі. Зонди конструктивно розділені на кілька частин, що дозволяє провести перевірку якості підключення.

Результати досліджень. Розроблено конструкцію багатозондового контактного пристрою і топологію притискання шлейфу, проведено моделювання напружено-деформованого стану, що виникає при притисканні зондів гнучкого шлейфу до виводів мікросхеми, проведені експериментальні дослідження перехідного опору гнучкий шлейф - виводи мікросхеми.

Висновки. Проведене моделювання та експериментальні дослідження дають підставу вважати, що запропоноване конструктивно-технологічне рішення дозволяє контролювати мікросхеми в BGA корпусах 3 кількістю виводів до декількох сотень і кроком розташування до 500мкм.

Ключові слова: BGA; багатозондовий контактний пристрій

Невлюдов И.Ш., Филипенко А.И., Палагин В.А., Разумов-Фризюк Е.А., Невлюдова В.В., Гурина Д.В.

Разработка конструкции МЭМС подключающих устройств с возможностью самотестирования подключения

Проблематика. Значительная часть современных электронных компонентов, применяемых в электронной технике, обладая высокими заявленными электрофизическими характеристиками, достаточно часто не соответствуют паспортным данным, имеют скрытые дефекты, которые ввиду сложности и высокого уровня интеграции (процессоры, FPGA и др.) трудно своевременно выявить. Это накладывает на производителей ЭТ дополнительные требования по организации входного и функционального контроля покупных изделий и использованию контролирующих устройств высокого уровня автоматизации и соответственно сложности.

Цель исследований. Разработка оригинального конструктивно-технологического решения многозондового контактного устройство для контроля микросхем в корпусах BGA, которое отличается возможностью одновременного контроля большого числа выводов с высокой плотностью их расположения, низкой себестоимостью, малыми массогабаритными параметрами и возможностью контроля качества подключения.

Методика реализации. Качественное, однородное контактирование многозондового контактного устройства к контролируемой микросхеме осуществляется за счет пневматического прижатия зондов, расположенных на гибком шлейфе. Зонды конструктивно разделены на несколько частей, что позволяет произвести проверку качества подключения.

Результаты исследований. Разработана конструкция многозондового контактного устройства и топология прижимающего шлейфа, произведено моделирование напряженно-деформированного состояния, возникающего при прижатии зондов гибкого прижимающего шлейфа к выводам микросхемы, проведены экспериментальные исследования переходного сопротивления гибкий шлейф - вывод микросхемы.

Выводы. Проведенное моделирование и экспериментальные исследования дают основание полагать, что предложенное конструктивно-технологическое решение позволяет контролировать микросхемы в BGA корпусах с количеством выводов до нескольких сотен и шагом расположения до 500мкм.

Ключевые слова: BGA; многозондовое контактное устройство 